\title{
Screening of the Breeding Lines of MTU1010 for Their Resistance against Bacterial Blight and Blast
}

\author{
B. Laxmi Prasanna ${ }^{1 *}$, Kuldeep Singh Dangi ${ }^{1}$, R. M. Sundaram ${ }^{2}$, C. H. Damodar Raju ${ }^{1}$, \\ R. Jagadeeshwar ${ }^{1}$, G. Rekha ${ }^{2}$ and Pragya Sinha $^{2}$ \\ ${ }^{1}$ Professor Jayashankar Telangana State Agricultural University, Rajendranagar, India \\ ${ }^{2}$ Indian Institute of Rice Research (ICAR-IIRR), Rajendranagar, India \\ *Corresponding author
}

\section{A B S T R A C T}

In the present study, we have introgressed two major genes, viz., Xa21 and Pi54 conferring resistance against bacterial blight (BB) and blast, respectively into an Indian rice variety

\section{Keywords}

Rice, Bacterial blight, Blast, Resistant genes,

Marker-aided selection, RILs

Article Info

Accepted:

28 June 2018

Available Online:

10 July 2018
MTU1010. Breeding line of Akshyadhan (RP6132) possessing Xa21 and Pi54 was used to transfer the target traits into the susceptible parent MTU1010, which is highly susceptible to both BB and blast diseases, which limits its spread to the disease endemic areas. Hence, an attempt was made to incoporate $\mathrm{BB}(\mathrm{Xa21})$ and blast (Pi54) resistance genes from breeding line of Akshyadhan which is highly resistant to the rice bacterial blight and blast diseases caused by the pathogen, Xanthomonas oryzae pv. oryzae (Xoo) and blast fungus Magnaporthe grisea respectively. The SES scale (IRRI, SES 2013) was used for visual scoring of bacterial blight and blast resistance in the segregating population and the resultant resistant progenies were advanced. This work demonstrates the successful application of Mendelein ratio for targeted introgression of a dominant BB and blast genes $(X a 21+$ Pi54) into a most popular rice variety, MTU 1010, a short duration, high yielding; long slender rice variety occupied maximum area in India particularly during dry-season. Our study exemplifies the improvement of the targeted popular variety MTU1010 for the multiple target traits.

\section{Introduction}

Rice blast disease was first reported as 'rice fever disease' in China by Soong Ying-shin in 1637 in India it was first reported in the Tanjavur delta of Tamil Nadu in 1913 (Srijan et al., 2015). MTU1010, a short duration rice variety released in 2000 derived from the cross Krishnaveni/IR64, is extremely popular with farmers and has been planted for many years in a minimum of one million hectares. This variety also possesses brown plant hopper resistance with long slender grains. However, MTU1010 is highly susceptible to both $\mathrm{BB}$ and blast diseases, which limits its spread to areas where the two diseases are endemic. In the absence of effective chemicals or any other methods of control agents against BB pathogen (Devadath et al., 1989), resistance breeding is considered as the most economical and ecofriendly strategy for management of the disease and achieving yield stability. As the availability of several resistance genes to $\mathrm{BB}$ and blast, pyramiding 
multiple genes into MTU1010 is considered as an ideal strategy to improve its resistance to these major diseases. Breeding for host-plant resistance is considered as the most economical and eco-friendly strategy for management of pests and diseases of crop plants and achieving yield stability. Molecular markers can accelerate resistance breeding efforts, as segregating plants can be selected on the basis of molecular marker alleles instead of their phenotypes and introgression of multiple resistance genes or gene pyramiding can be tracked easily in a population (Sundaram et al., 2014).

Due to apparent changes in the climate, these two diseases may cause heavy yield loss. The deployment of resistance genes in rice breeding programme and cultivation of resistant varieties is considered as most effective, economical and environment friendly strategy to manage the plant diseases. Pyramiding blast and $\mathrm{BB}$ resistance genes in a single cultivar will help in tackling both the disease problems.

Two most devastating diseases in rice, blast caused by the fungus Magnaporthe grisea and bacterial blight caused by Xanthomonas oryzae pv. Oryzae throughout Asia and particularly in India, have plagued rice farmers since the beginning of rice cultivation (Ou, 1985) and can cause yield loss as high as $50 \%$ or more. Sometimes, both the diseases may occur together or at different period of growth stages causing severe loss to rice crop (POS, 2008). Due to apparent changes in the climate, these two diseases may cause heavy yield loss. The deployment of resistance genes in rice breeding programme and cultivation of resistant varieties is considered as most effective, economical and environment friendly strategy to manage the plant diseases. Rice is the principal staple food crop of the world and rice production has so far kept pace with the growing population, principally due to cultivation of high-yielding, high-input demanding, and semi-dwarf varieties (Gnanamanickam, 2009). However, the introduction of semi-dwarf rice varieties and the large-scale use of inputs like fertilizers and insecticides have changed the dynamics of pests and diseases of rice, increasing their incidence significantly in the recent years. Bacterial blight (BB) and rice blast are the two most important diseases causing significant yield loss in rice (Zhang et al., 2015), and they are endemic to several rice growing states of India (Production Oriented Survey, DRR, 2008). In Andhra Pradesh of India, the yield loss is very severe due to $\mathrm{BB}$ and blast (Rajarajeswari and Muralidharan, 2006, Sundaram et al., 2008). It also implies to the newly formed state of Telangana. To minimize these problems, development of durable, broad-spectrum resistant varieties has been advocated (Jena and Mackill, 2008, Kumar et al., 2014, Sundaram et al., 2014).

Till date, at least $40 \mathrm{BB}$ resistance (both dominant and recessive) genes have been identified (Bhasin et al., 2012; Natrajkumar et al., 2012) and designated these in a series from Xal to Xa40 (Yang et al., 1998; Sun et al., 2004; Gu et al., 2004; Cheema et al., 2008; Kim et al., 2015). Of these, Xa21, a major resistance gene, originally introgressed from Oryza longistaminata was observed to confer resistance to most Indian isolates of the bacterial pathogen. The gene has also been reported to confer durable resistance to the pathogen across many parts of the world including India (Sundaram et al., 2014). To date, 101 blast-resistant genes (Rajashekara et al., 2014) and 350 quantitative trait loci (QTLs) have been identified (Sharma et al., 2012), with many fine-mapped and a few cloned. Among these, Pi54, a major blast resistant gene from the Vietnamese cultivar, Tetep has been identified to be highly effective under Indian conditions (Sharma et al., 2010). 


\section{Materials and Methods}

\section{Plant material}

Breeding lines of Akshydhan carrying BB and blast resistant genes $\mathrm{Xa21}$ and Pi54 were used to transfer resistant genes into MTU1010, a susceptible variety to both the diseases. In addition to this Taichung Native 1(TN1), HR12 were used as susceptible checks, while ISM, Tetep were used as resistant checks for $\mathrm{BB}$ and blast resistance respectively. The seeds of true $F_{1}$ plants obtained from the above mentioned cross between the parents were selfed to obtain $\mathrm{F}_{2} \mathrm{~S}$ and a total of $274 \mathrm{~F}_{2}$ plants were obtained. The plants which were observed to be highly resistant under $\mathrm{BB}$ stress were forwarded to $F_{3}$ generation and screened for both the target stresses.

\section{Isolation and characterization of the blast and bacterial blight pathogen}

M. grisea was isolated from the blast infected leaf samples of the rice cultivar HR-12 on oat meal agar medium (Rathour et al., 2006). To obtain a single spore colony, spore suspension was prepared and plated onto $4 \%$ water agar in Petri plates. After 10-12 hours of incubation at $25 \pm 1^{0} \mathrm{C}$, single germinating conidia were marked under a microscope and transferred to fresh culture medium. The purified culture was maintained in oat meal agar slants at $4^{0} \mathrm{C}$.

To prove pathogenicity of the M. grisea, the fungus was mass multiplied on Mathur's medium (Rathour et al., 2006). After 8-10 days of incubation at $25 \pm 1^{0} \mathrm{C}$, the plates were gently washed with distilled water to harvest conidia. The suspension was then filtered through muslin cloth and the spore concentration was adjusted to $1 \times 10^{9}$ conidia/ml. Fifteen days old seedlings of rice variety HR-12 was inoculated by spraying the spore suspension (containing $0.2 \%$ Tween 20 ). The inoculated plants were kept in a humid chamber maintained at $25^{\circ} \mathrm{C}$ and sprayed with water three to four times a day to maintain high humidity. The bacterial blight pathogen, Xanthomonas oryzae $p v$. oryzae was isolated from the infected leaf samples on modified Wakimoto's medium and maintained as pure culture at $4^{0} \mathrm{C}$. The pathogenicity of the bacterial pathogen was confirmed on susceptible rice variety $\mathrm{TN} 1$.

\section{Screening of the $F_{2}$ and $F_{3}$ population}

Blast: The $\mathrm{F}_{3}$ population along with respective parents was evaluated for their reaction to blast disease under uniform blast nursery. The plants were sown in rows and were surrounded with the densely sown spreader rows of susceptible cultivar HR-12. To create severe blast incidence additional inoculum was sprayed. For this, diseased leaves were chopped into pieces of $3-6 \mathrm{~cm}$ long and scattered them over the plot. This was carried during prolonged wet weather to facilitate infections and polycyclic development of the disease. The seedlings at 4-leaf stage were sprayed with spore suspension of a highly virulent isolate of $M$. grisea (IIRR SP - 28). High humidity was maintained for good disease development. The disease reaction was recorded 15 days after inoculation on each plant following 0-9 scale (IRRI, 1996).

Bacterial blight: The $\mathrm{F}_{2}$ and $\mathrm{F}_{3}$ plants along with the checks ISM (resistant check) and TN1 (susceptible check) were transplanted in plastic trays. The bacterial pathogen was multiplied on modified Wakimoto's medium at $28 \pm 11^{\circ} \mathrm{C}$. Plants at maximum tillering stage were clip inoculated with three day old bacterial suspension (0.1 O.D.) (Kauffman et al., 1973). Observations were recorded 14 days after inoculation by measuring the lesion length. The Lines were categorized as resistant (lesion length d" $4 \mathrm{~cm}$ ), moderately resistant (lesion length 4.1-8 cm) or susceptible (lesion length $>8 \mathrm{~cm}$ ) (Shanti et al., 2001). 


\section{Results and Discussion}

\section{Phenotypic analysis of $F_{2}$ plants for Bacterial blight resistance}

$274 \mathrm{~F}_{2}$ plants were obtained from the cross between NILs of MTU1010 and breeding lines of Akshyadhan. These were phenotyped for bacterial blight reaction. Out of $247 \mathrm{~F}_{2}$ plants (Table-1) evaluated against BB, 97 plants were found resistant (lesion length <3), 54 were found to be moderately resistant (lesion length 3.1-5.0), 84 were found to be moderately susceptible (lesion length 5.1-7.0) and 39 were found to be highly susceptible (lesion length >7.1) (Table 1).

Phenotyping for bacterial blight and blast resistance genes in $F_{3}$ population

Ninety seven resistant plants (Table-1) obtained from screening of the $\mathrm{F}_{3}$ population from the cross MTU1010 x Akshyadhan was advanced to $\mathrm{F}_{3}$ generation. These were phenotyped with bacterial blight isolate and all were observed to be resistant to $\mathrm{BB}$ (lesion length $<3 \mathrm{~cm})$. The selected lines were advanced further to obtain promising lines possessing both blast and bacterial blight resistance genes.

Acharya N.G Ranga Agricultural University (ANGRAU), Andhra Pradesh and Professor Jayashankar Telangana State Agricultural University (PJTSAU), Telangana state played an important role in Indian agriculture by releasing many popular varieties and hybrids in almost all the crops especially in rice. Among the 10 mega rice varieties, four rice varieties viz., Cottondora Sannalu (MTU1010), Samba Mahsuri (BPT5204), Swarna (MTU7029) and Vijetha (MTU1001) are released from ANGRAU and three upcoming verities viz., Telangana sona (RNR 15048), Kunaram sannalu (KNM 118) and Bathukamma (JGL 18047) from PJTSAU, have occupied more than $25 \%$ of area in India and more than half of the area in Telangana. Among which, Cottondora Sannalu (MTU1010), is covering $>12 \%$ (Vanisree et al., 2012) of Indian rice acreage because of its wider adaptability to the $\mathrm{BPH}$ resistance and its high yielding, but susceptible to bacterial blight (BB) and blast diseases, which causes significant yield losses in many states of India including Andhra Pradesh. In order to sustain the yield levels of rice cultivars like MTU 1010 , it is imperative to improve the variety for disease resistance. In the absence of effective chemicals or any other methods of control agents against BB pathogen (Devadath et al., 1989), resistance breeding is considered as the most economical and ecofriendly strategy for management of the disease and achieving yield stability. Pyramiding resistance genes is difficult to accomplish using conventional breeding strategy due to epistatic effects of genes controlling resistance and due to non-availability of screening facilities for multiple biotic stresses in addition to screening restricted only to specific seasons. Molecular markers can accelerate resistance breeding efforts (Sundaram et al., 2008), as segregating plants can be selected on the basis of molecular marker alleles instead of its phenotype and introgression of multiple resistance genes can be tracked easily in a population.

Among several biotic stresses that cause significant yield losses in rice, bacterial blight (BB) and rice blast are the two major biotic stresses, particularly in Punjab, Andhra Pradesh, Haryana and Uttar Pradesh (including parts of Uttaranchal) mainly in the irrigated and rainfed low land ecosystems (Production Oriented Survey, 2008). Bacterial blight is one of the most destructive diseases of rice worldwide caused by Xanthomonas oryza pv. oryzae (Xoo) and the yield losses can be as high as $50 \%$ and can be assumed to epidemic proportions. 
Table.1 Segregation pattern of $F_{2}$ generation against bacterial blight resistance

\begin{tabular}{|c|c|c|c|c|c|c|c|c|c|}
\hline \multirow[t]{2}{*}{ Cross } & \multicolumn{4}{|c|}{$\begin{array}{l}\text { Frequency distribution for BLB } \\
\text { disease score }(\mathrm{cm})\end{array}$} & & \multicolumn{2}{|c|}{$\begin{array}{l}\text { Observed } \\
\text { frequency }\end{array}$} & \multicolumn{2}{|c|}{$\begin{array}{l}\text { Expected } \\
\text { frequency }\end{array}$} \\
\hline & $<3$ & $\begin{array}{l}3.1 \text { to } \\
5.0\end{array}$ & $\begin{array}{l}5.1 \text { to } \\
7.0\end{array}$ & $\geq 7.1$ & $\begin{array}{l}\text { Total no of } \\
\text { plants }\left(\mathrm{F}_{2}\right)\end{array}$ & $\mathrm{R}$ & $\mathrm{S}$ & $\mathrm{R}$ & $\mathrm{S}$ \\
\hline $\begin{array}{c}\text { NILs of } \\
\text { Akshyadhan }\end{array}$ & 54 & 0 & 0 & 0 & 54 & 54 & 0 & 54 & 0 \\
\hline MTU1010 & 0 & 0 & 44 & 12 & 56 & 0 & 56 & 0 & 56 \\
\hline $\begin{array}{c}F_{2} \text { population of } \\
\text { Akshyadhan } X \\
\text { MTU1010 }\end{array}$ & 97 & 54 & 84 & 39 & 274 & 151 & 123 & 154 & 120 \\
\hline
\end{tabular}

Table.2 Screening details of $\mathrm{F}_{3}$ generation against blast resistance

\begin{tabular}{|c|c|c|c|c|c|c|}
\hline Cross & \multicolumn{7}{|c|}{ Frequency distribution for blast disease score } & \\
\hline NILs of Akshyadhan & 0 & $1-3$ & $4-5$ & $6-7$ & $8-9$ & $\begin{array}{c}\text { Total no of } \\
\text { lines }\left(\mathrm{F}_{3}\right)\end{array}$ \\
\hline $\begin{array}{c}\text { MTU1010 } \\
\text { NILs of Akshyadhan } \\
\begin{array}{c}\text { X MTU1010 } \\
\hline\end{array}\end{array}$ & 0 & 51 & 0 & 0 & 0 & 51 \\
\hline
\end{tabular}

Management of BB through application of chemicals/antibiotics is not commercially available (Devadath, 1989 and Gnanamanickam et al., 1999). Hence, deployment of varieties with resistant genes is the only approach. Large scale and long term cultivation of varieties with single gene may enable the pathogen to overcome BB resistance. The most effective approach to combat bacterial blight is the use of resistant varieties with combination of different genes (Khush et al., 1989). Till date, at least 40 BB resistance (R) genes conferring host resistance against various strains of Xoo have been identified. Suh et al., (2013) reported that among the $40 \mathrm{R}$ genes, six are physically mapped (Xa2,Xa4,Xa7, Xa30, Xa33 and $X a 38)$ and six are cloned (Xal, xa5, xal3, $X a 21, X a 26=X a 3$ and Xa27). Of these, Xa21, a major resistance gene, originally introgressed from Oryza longistaminata (Ronald et al., 1992; Song et al., 1995) was observed to confer resistance to most Indian isolates of the bacterial pathogen.

The fungus Magnaporthe oryzae is the causal agent of rice blast disease and belongs to phylum, Ascomycota and family Magnaporthaceae. It is one of the most devastating diseases in at least 85 countries worldwide. The disease often results in a significant yield loss, as high as $70-80 \%$ during an epidemic $(\mathrm{Ou}, 1985)$. Hence there is an urgent need to improve this restorer line by incorporating resistance genes of bacterial blight and blast. As on date, 100 rice blast major resistance genes (R-genes) have been identified (Sharma et al., 2012) and among the major blast resistance genes, $P i-k^{h}$, which has been recently renamed as Pi54 (Sharma $e t$ al., 2010), exhibited resistance to predominant races of the pathogen in India (Sharma et al., 2002). Pi54 gene was originally identified from Tetep, a Vietnam 
indica source and mapped on chromosome $11 \mathrm{~L}$ with two tightly linked simple sequence repeat (SSR) markers TRS26 and TRS33 has been cloned (Sharma et al., 2005). Ramkumar et al., (2011) developed PCR based functional marker Pi54MAS and it was observed to perfectly co-segregate with no recombinants. The rice cultivar 'Tetep' has been found to be resistant to most of the pathogenic races occurring in India (Padmanabhan et al., 1979). A recently developed Near Isogenic Line (NIL) line of Akshyadhan (Bhaskar et $a l ., 2016)$ with long slender grain type, indica rice variety derived from the cross Akshyadhan/RPBio Patho-2 possessing Xa21 for BB and Pi54 for blast along with good grain yield.

We selected only a single dominant gene each conferring resistance against $\mathrm{BB}$ (i.e. $\mathrm{Xa21}$ ) and blast (i.e. Pi54) in the present study. Even though there are a few previous reports about breakdown of resistance conferred by a single BB resistance gene (Mew et al., 1992, Khush et al., 1989) in rice, till date there is no report about large-scale breakdown of resistance conferred by either Xa21 or Pi54 from India or abroad. Further, as per a recent report (DRR annual report, 2011-12), NILs of Samba Mahsuri and Swarna possessing only Pi54 displayed resistance across multiple locations in India (DRR Progress report, Vol. 2, 2008-2013).

In conclusion, through the present study, we have developed $F_{2}$ and $F_{3}$ population of the popular variety MTU1010 possessing resistance against $\mathrm{BB}$ and blast. When we screened the $274 \quad F_{2}$ plants of MTU1010 against the predominant isolates of $\mathrm{BB}$ (DXO-020) and blast (SPI-40) (Table-1), the RILs were segregated by Mendelian ratio (9:3:3:1) and observed to be highly susceptible (120) and resistant (154) against both the diseases. Further, the highly resistant 97 plants were forwarded to $F_{3}$ generation thus indicating that the RILs have tremendous potential for development of elite LS grain type, $\mathrm{BB}$ and blast resistance.

\section{Acknowledgements}

The authors are thankful to PJTSAU, Telangana and the Director, IIRR for providing the facilities, financial assistance and encouragement.

\section{References}

Bhasin H, Bhatia D, Raghuvanshi S, Lore JS, Sahi GK, Kaur B, et al., 2012. New PCR-based sequence-tagged site marker for bacterial blight resistance gene $\mathrm{Xa38}$ of rice. Molecular Breeding. 30: 607611.

Cheema KK, Grewal NK, Vikal Y, Sharma R, Lore JS, Das A, Bhatia D, et al., 2008. A novel bacterial blight resistance gene from Oryza nivara mapped to $38 \mathrm{~kb}$ region on chromosome 4 and transfered to Oryza sativa L. Genetical Research. 90:111.

Devadath, S. 1989. Chemical control of bacterial blight of rice. In Bacterial blight of rice. International Rice Research Institute, Manila, Philippines. 89-98.

Gnanamanickam, Rice and its importance to human life Prog Biol Con, 8 (2009), pp. 1-11.

Gu K, Tian D, Yang F, Wu L, Sreekala C, Wang D, et al., 2004. High-resolution genetic mapping of $\mathrm{Xa27}(\mathrm{t})$, a new bacterial blight resistance gene in rice, Oryza sativa L. Theor Appl Genet. 108:800-807.

IRRI, 1996. Standard Evaluation System for Rice. 4th Edn., International Rice Research Institute, Manila, Philippines.

Jena, KK, Mackill, DJ. Molecular markers and their use in marker-assisted 
selection in rice Crop Sci, 48 (4) (2008), pp. 1266-1276.

Kauffman HE, Reddy APK, Hsieh SPY and Merca SD, 1973. An improved technique for evaluating resistance of rice varieties to Xanthomonas oryzae. Plant Dis. Rep. 56: 537-540.

Khush GS, MacKill DJ and Sidhu GS, 1989. Breeding rice for resistance to bacterial blight. Proceedings of International Workshop on Bact. Blight Rice. IRRI, Manila, Philippines. 207-217.

Kim SM, Suh JP, Qin Y, HNoh T, Reinke RF and Jena KK. 2015. Identification and fine mapping of a new resistance gene, $X a 40$, conferring resistance to bacterial blight races in rice (Oryza sativa L.). Theor Appl Genet. doi: 10.1007/s00122015-2557-2.

Kumar A, Dasgupta P and Kumar R. 2014. Emerging opportunities and challenges in rice production Pop Kheti, 2 (2), pp. 6-11.

Mew TW, Vera Cruz CM and Medalla ES. 1992. Changes in race frequency of Xanthomonas oryzae pv. Oryzae in response to rice cultivars planted in the Philippines. Plant Diseases. 76: 10291032.

Natraj kumar P, Sujatha K, Laha GS, Srinivasarao K, Mishra B, Viraktamath BC, et al., 2012. Identification and finemapping of Xa33, a novel gene for resistance to Xanthomonas oryzae pv. Oryzae. Phyto Path. 102, 222-228.

Ou SH. 1985. Common wealth Mycological Institute. Rice diseases. Kew.

Production Oriented Survey (POS). 2008. DRR, ICAR, Hyderabad, India.

Rajarajeswari NVL, Muralidharan K. 2006. Assessments of farm yield and district production loss from bacterial leaf blight epidemics in rice Crop Prot, 25 (3), pp. 244-252.

Rajashekara H, Ellur RK, Khanna A, Nagarajan M, GopalaKrishnan S, Singh
AK, et al., 2014. Inheritance of blast resistance and its allelic relationship with five major $R$ genes in a rice landrace 'Vanasurya' Ind Phytopathol, 67 (4), pp. 365-369.

Ramkumar G, Srinivasa Rao K, Madhan Mohan K, Sudarshan I, Sivaranjani AKP, Gopala Krishna K, et al., 2011. Development and validation of functional marker targeting an In Del in the major rice blast disease resistance gene Pi54 (Pikh). Molecular Breed. 27: 129-135.

Rathour, R, Singh, BM and Plaha, P. 2006. Virulence structure of the Magnaporthe grisea rice population from the North western Him alayas. Phytoparasitica 34: 281291. doi:10.1007/BF029 80957.

Ronald PC, Albano B, Tabien R, Abenes MLP, Wu KS, McCouch SR. et al., 1992. Genetic and physical analysis of the rice bacterial blight disease resistance locus Xa21. Mol. Gen. Genet. 236: 113-120.

Shanti, ML, George MLC, Cruz VCM, Bernando Ma, Nelson RJ, Leung $\mathrm{H}$, et al.,2001. Identification of resistance genes effective against rice bacterial leaf blight pathogen. Plant Dis. 85: 506512.

Sharma TR, Madhav MS, Singh BK, Shanker P, Jana TK, Dalal V, et al., 2005. High resolution mapping, cloning and molecular characterization of the Pikh gene of rice, which confers resistance to M. grisea. Molecular Genetics and Genomics. 274: 569-578.

Sharma TR, Rai AK, Gupta GK and Singh NK, 2010. Broad spectrum blast resistance gene Pikh cloned from the rice line tetep designated as Pi54. J Plant Biochem Biotechnol. 19: 1.

Sharma TR, Rai AK, Gupta SK, Vijayan J, Devanna BN and Ray, S, 2012. Rice Blast Management Through Host-Plant 
Resistance: retrospect and Prospects. Agric Res.1:37-52.

Song W.Y., Wang G.L., Chen L.L., Kim HS, Pi, LY. Holsten T, Gardner, Wang B, Zhai WX, Zhu LH, Fauquet, C and Ronald, PC. 1995. A receptor kinaselike protein encoded by the rice disease resistance gene, Xa21. Science. 270: 1804-1806.

Srijan, A., Sudheer Kumar, S., Jagadeeshwar, $\mathrm{R}$ and Damodar Raju, Ch. 2015. Identification of the better parents and hybrids for blast resistance by UBN (Uniform Blast Nursery) method in rice (Oryza sativa L.). Research Journal of Agricultural Sciences. 6(4): 892-895.

Suh JP, Ji-UngJeung, Tae-Hwan Noh, YoungChan Cho, So-Hyun Park, Hyun-Su Park, Mun-Sik Shin, Chung-Kon Kim and Kshirod K Jena, 2013. Development of breeding lines with three pyramided resistance genes that confer broad-spectrum bacterial blight resistance and their molecular analysis in rice. Rice. 6: 5.

Sun X, Cao Y, Yang Z, Xu C, Li X, Wang S and Zhang Q, 2004. Xa26, a gene conferring resistance to Xanthomonas oryzae pv. oryzae in rice, encodes an LRR receptor kinase-like protein. Plant J. 37: 517-527.

Sundaram RM, Subhadeep Chatterjee, Ricardo Oliva, Laha GS, Jan E Leach, Ramesh V Sonti et al., 2014. Update on Bacterial Blight of Rice: Fourth
International Conference on Bacterial Blight. Rice. 7: 12.

Sundaram RM, Vishnupriya MR, Biradar SK, Laha GS, Reddy AG, Rani NS, et al., 2008. Marker assisted introgression of bacterial blight resistance in Samba Mahsuri, an elite indica rice variety. Euphytica. 160: 411-422.

Vanisree, S., Durga Rani, Ch.V. Aruna Kumari, K., Jagadeeswar, R., Sreedhar, M., Ramesh Babu Y et al., 2012. Molecular marker analysis of promising rice cultivars for pi-1., pi-2 and pik-h blast resistant genes. International symposium on "100 years of Rice Science and Looking Beyond" during January 9-12, 2012. Volume 1, 108-110 at Tamil Nadu Agricultural University, Coimbatore, Tamil Nadu, India.

Yang Q, Saito K, Yang P, Wang Q, Sunohara $\mathrm{Y}$, Zheng F, et al., 2001. Molecular mapping of a new blast resistance gene $P$ i25 (t) possessed in a Japonica rice cultivar, Orizasativa L. cv. Yunxi. 2: 49-55. In proc general meeting Rice blast in china Kunming.

Zhang F, Huang LY, Zhang F, Ali J, Cruz VC, Zhuo DL, et al., 2015. Comparative transcriptome profiling of a rice line carrying $\mathrm{Xa} 39$ and its parents triggered by Xanthomonas oryzae $p v$. oryzae provides novel insights into the broad-spectrum hypersensitive response. BMC Genomics. 16: 111.

\section{How to cite this article:}

Laxmi Prasanna B., Kuldeep Singh Dangi, R. M. Sundaram, C. H. Damodar Raju, R. Jagadeeshwar, G. Rekha and Pragya Sinha. 2018. Screening of the Breeding Lines of MTU1010 for Their Resistance against Bacterial Blight and Blast. Int.J.Curr.Microbiol.App.Sci. 7(07): 4077-4084. doi: https://doi.org/10.20546/ijcmas.2018.707.474 